\title{
Developing Reading Automaticity and Fluency: Revisiting What Reading Teachers Know, Putting Confirmed Research into Current Practice
}

\author{
Gail M. Wolf \\ Oregon Health \& Science University, Portland, OR, USA \\ Email: wolfg@ohsu.edu
}

How to cite this paper: Wolf, G. M. (2018). Developing Reading Automaticity and Fluency: Revisiting What Reading Teachers Know, Putting Confirmed Research into Current Practice. Creative Education, 9, 838-855. https://doi.org/10.4236/ce.2018.96062

Received: April 5, 2018

Accepted: May 11, 2018

Published: May 14, 2018

Copyright $\odot 2018$ by author and Scientific Research Publishing Inc. This work is licensed under the Creative Commons Attribution International License (CC BY 4.0).

http://creativecommons.org/licenses/by/4.0/

\section{cc) (i) Open Access}

\begin{abstract}
This article revisits research on reading automaticity and fluency with the goal of helping beginning reading teachers put confirmed research findings into current classroom practice. The article examines the concepts of automaticity and fluency, how both impact the development of skillful reading. The article reviews research on: a) reading strategies children use, and b) repeat reading teaching strategies to develop fluency. Case scenarios illustrate key findings. Based on the research and case scenarios, four conclusions are drawn: 1) The terms automaticity and fluency are often interchanged; the concepts are not the same; 2) Understanding the differences between automaticity and fluency can impact repeat reading teaching strategies; 3 ) There is an assumption that rapid word recognition is the same cognitive process as automatic word decoding, and 4) There are two pathways to fluent reading, rapid word recognition, and automatic decoding ability. The article presents a theoretical model which aligns with childhood learning theories, offering teachers a variation in repeat reading teaching strategies. Rather than repeating reading the same text, opportunities to read slightly different, decodable text improves decoding, builds fluency, and thus strengthens children's reading comprehension of complex text.
\end{abstract}

\section{Keywords}

Beginning Reading Instruction, Automaticity, Fluency, Repeat Reading, Word Decoding

\section{Introduction}

The purposes of this article are to: a) review the seminal literature to define 
reading automaticity and reading fluency, noting the differences between the concepts; b) explore repeat reading theories and repeat reading teaching practices to help children develop reading fluency; c) contrast and compare the terms of rapid word recognition and automatic word decoding; and d) show how teachers of beginning reading can put accepted past research findings into current classroom practice. Literature and case scenarios show repeat reading practices may be useful for helping children develop rapid word recognition and fluent reading; some repeat reading methods fail to adequately help children develop needed automatic word decoding skills. The article offers a theoretical model of how the reading materials presented to children play a critical role in the children's development of decoding automaticity, reading fluency, and comprehension of complex text. The final section explores how childhood teaching and learning theories support the theoretical model; both the model and childhood learning theories should be a part of reading teacher education.

\section{Defining Terms and Clarifying Assumptions}

This article is written within the context of the beginning reader, and beginning reading instruction. For the purposes of this article the beginning reader means young children experiencing the first, formal reading lessons. The beginning reader refers to children ages four through seven.

\subsection{Defining Reading}

Reading is defined as the ability to look at print, respond with the proper sound translation and comprehend the meaning of the print (Kostewicz \& Kibina, 2010; National Institute of Child Health and Human Development, 2000). Reading is a complex skill of constructing meaning from written text; the reader must be able to decode words quickly and accurately so the mind is free to comprehend the text (Kuhn, Schwanenflugel, \& Meisinger, 2010). This essential, rapid decoding skill proficient readers have is called automaticity (Adams, 1990; Kuhn et al., 2010; La Berge \& Samuels, 1974; Logan, 1997).

\subsection{Defining Decoding}

Decoding is defined as the ability to look at print and respond with the proper sound translation; decoding is a print-to-sound process (Adams, 1990; De Graaff, Bosman, Hasselman, \& Verhoeven, 2009). Decoding refers to the ability to attend to letter sound translations, and spelling patterns to decipher a word. This definition of decoding follows research from Castles \& Nation (2008), Ehri (2005), Hoien-Tengesdal and Tonnessen (2011), and Veenendaal, Groen, and Verhoeven (2015) who describe decoding as the ability to connect letters and spelling-patterns to the proper sound translation.

\subsection{Defining Decodable Text}

For the purposes of this article, the term decodable text refers to simple, regular 
spelling patterns with short vowel sounds. Examples of decodable text are the consonant-vowel-consonant (CVC) pattern, /a/, /o/, /i/, /u/, and, /e/ words: hat, mop, wig, fun, and men; about 250 words, only one spelling pattern (Appendix). Examples of other decodable text are the CVCC pattern: pass, doll, puff, kiss, bell, ...camp, damp, lamp...belt, felt, melt... The CCVC pattern: skid, skin, skip, stop, step, snip, spin, spot, swam swim... The CCVCC pattern: black, crack, speck, brick, click, stick, trick, block, clock, stuck, truck... This definition of decodable text aligns with research from Adams (1990), Denton and Otaiba (2011), and Greaney and Arrow (2012).

\subsection{Defining Automaticity}

Automaticity is defined as the ability of a reader to decode print instantly without conscious thought or effort (Kuhn et al., 2010; La Berge \& Samuels, 1974; Logan, 1997). Automaticity is linked to reading comprehension; when a reader does not have to consciously think about decoding, the reader's mind is free to comprehend text (Adams, 1990; Kostewicz \& Kibina, 2010; Kuhn et al., 2010; National Institute of Child Health and Human Development, 2000). One root cause of poor reading comprehension is lack of automatic decoding skill (Adams, 1990; Kuhn et al., 2010; La Berge \& Samuels, 1974; Logan, 1997). A main goal of reading instruction is to help children acquire automatic decoding ability (Deeney, 2010; De Graaff et al., 2009).

\subsection{Defining Fluency}

Fluency is defined as fast, accurate oral reading with proper expression (Kuhn et al., 2010; National Institute of Child Health and Human Development, 2000; Rasinski, 2012; Schwanenflugel et al., 2006). Beginning reading teachers check for reading automaticity by monitoring reading fluency, often focusing on speed of words read correctly per minute (wcpm) (Deeney, 2010; Guerin \& Murphy, 2015; Rasinski, 2012). Developing reading fluency is a national Common Core Standard of teaching practice (Common Core State Standards Initiative, CCSSI, 2015; Common Core State Standards, CCSS, 2015).

As with reading automaticity, reading fluency is tied to reading comprehension (Guerin \& Murphy, 2015). Studies also show a connection between proper oral expressive reading (prosody) and improved reading comprehension (Keyes, Cartledge, Gibson, Lenwood, \& Robinson-Ervin, 2016; Paige, Rasinski, \& Magpuri-Lavell, 2012; Veenendaal et al., 2015).

\subsection{The Merging of Two Concepts, Automaticity and Fluency}

The concept of developing reading fluency began to merge with the concept of reading automaticity (National Institute of Child Health and Human Development, 2000: p. 3-7). At times, the terms reading fluency and reading automaticity have merged in the literature; Rasinski (2012: p. 518) writes, "Because fluency (automaticity) has come to be measured by a reader's speed of reading..." 
Researchers agree, gaining automatic decoding skills helps lead to fluent oral reading (Adams, 1990; Kuhn et al., 2010; Samuels, 1979). The rub is, should the beginning reading instructor strive for oral reading fluency during beginning reading attempts. The following scenario shows instead, the teacher focusing on independent, accurate reading, with comprehension.

\subsection{Case Scenario}

Nelly is a four-year-old who would not talk. Teachers are still able to teach Nelly to read. First, Nelly would listen to a teacher verbalize a single letter-sound, Nelly would point to the corresponding, lower case letter. Because Nelly would not talk, the option of the teacher pointing to a letter and Nelly responding verbally with the basic sound translation was omitted. Instead, after Nelly could successfully point to 9 letters the teacher verbally "sounded", Nelly was ushered into reading lessons. Nelly would sit at a table with her teacher. On the table were little toys set up in a row: a rat, a man, a mat, a van, a can, a cat, a hat. The teacher would offer a word on a large strip of paper: van. Nelly had to read the word, and select the item the word represented. Thus, there was silent reading, independent reading, and documentation of reading comprehension. The teacher has no idea if Nelly's reading is fluent.

When children are first learning to read, the speed of oral reading is individualized (Wolf, 1998; 2014). Veenendaal et al. (2015) note when children are learning to read, the reading is not fluent. Further, reading teachers should not expect first reading attempts to be fluent because children are learning to decode (Veenendaal et al., 2015). Yet children must eventually develop reading fluency (Veenendaal et al., 2015).

\section{Repeat Reading to Develop Reading Fluency}

A main strategy to help young readers develop fluent reading is repeat reading (Deeney, 2010; National Institute of Child Health and Human Development, 2000). Repeat reading is a strategy in which a child reads the same text over and over until the oral reading becomes fluent (Deeney, 2010; Hicks, 2009; National Institute of Child Health and Human Development, 2000; Samuels, 1979; 1985). This section explores the repeat reading theories of Jay Samuels, and Carol Chomsky along with other repeat reading research. Next, the section explores repeat reading teaching practices to help children develop reading fluency.

\subsection{Samuels' Repeat Reading Theory and Assumptions}

Some repeat reading teaching strategies can be traced back to Samuels' (1985) seminal writings. Samuels theorized if children repeat read the same text to fluency the children will gain automatic decoding skills (Samuels, 1979; 1985; Samuels \& Flor, 1997; Samuels, Schermer, \& Reinking, 1992). Samuels (1979; 1985) asserted repeat reading is a process of practicing rapid decoding. Samuels wrote,

"We assume that, because of the extensive practice on rapid recognition of these 
words, the words are decoded automatically" (Samuels, 1985: p. 228). The assumption is rapid word recognition involves the same mental processing as automatic word decoding.

\subsection{Chomsky's Repeat Reading Theory and Assumptions}

Carol Chomsky at Berkeley was also using repeat reading methods (Chomsky, 1976). Chomsky surmised repeat reading increased overall reading success, yet reported the repeat reading technique helps children who cannot decode, memorize text (Chomsky, 1976). Unlike Samuels, Chomsky did not deduce that repeat reading techniques help develop children's decoding skills, but rather repeat reading helps children memorize text and rapidly recognize words to develop a sense of decoding success (Chomsky, 1976).

Some beginning reading teachers agree with Chomsky's theory, that repeat reading the same text to fluency helps children memorize text (A. Zaichenko, personal communication, October 11, 2018). A first grade teacher reports, "Children can repeat read a paragraph to rapid, accurate, and expressive, fluent reading. Often, we teachers can take a simple word out of the paragraph's context, like the word man, and the children have no idea how to read the word." The teacher goes on to explain, "The children are learning to memorize a specific text; the children are not learning to read" (A. Zaichenko, personal communication, October 11, 2018).

\subsection{Repeat Reading Research}

The four repeat reading teaching strategies are: a) children echo-read after a teacher, b) children read with a tape-recorded voice reading the text, c) children choral read with entire class, and d) children repeat read text independently (Faulkner \& Levy, 1999; Homan, Klesius, \& Hite, 1993; Labbo \& Teale, 1990; National Institute of Child Health and Human Development, 2000; Sindelar, Monda, \& O'Shea, 1990).

A majority of early studies found repeat reading the same text to fluency helped children improve decoding, and ultimately improve children's reading comprehension of the specific text repeatedly read (Faulkner \& Levy, 1999; Homan et al., 1993; Labbo \& Teale, 1990; O’Shea, Sindelar, \& O’Shea, 1985; Sindelar et al., 1990). Most initial repeat reading studies did not attempt to measure decoding transfer skills to new text (National Institute of Child Health and Human Development, 2000: p. 3-15).

Other studies found, although repeat reading techniques may improve children's reading fluency of the repeated text; repeat reading interventions did not correlate to improved reading comprehension (Deeney, 2010; Fleisher, Jenkins, \& Pany, 1979; Hicks, 2009; Kuhn, 2005; Samuels, 1985; Therrien \& Hughes, 2008; Valencia et al., 2010). Some studies found repeat reading using different text increases reading comprehension more than repeat reading the same text (Kuhn, 2005; Therrien \& Hughes, 2008).

Today repeat reading continues to be a strategy used in classrooms with the 
purpose of developing children's automatic word decoding skill (Guerin \& Murphy, 2015). However, in the past, the term automatic word decoding has been interchanged with the term rapid word recognition (Samuels, 1985). Accordingly, there needs to be a close examination of the terms rapid word recognition, and automatic word decoding.

\section{Rapid Word Recognition and Automatic Word Decoding}

There is agreement that beginning readers need opportunities to decode text so the skill can become automatic (Adams, 1990; Cohen \& Brady, 2011; Denton \& Otaiba, 2011; Hoien-Tengesdal \& Tonnessen, 2011; Mc Candliss, Beck, Sandak, \& Perfetti, 2003; Samuels, 1985). However, beginning readers will often use non-decoding strategies to rapidly recognize words (Juel \& Roper/Schneider, 1985). The following case scenarios illustrate how children use many different strategies to read words.

\section{1) Case Scenario}

Mark is five. He looks at the word mom and says, "Mom. I know that word, 'm' 'o' 'm' (em-oh-em), mom." Mark fluently verbalizes the word mom; he spells and says the word mom. Mark has no idea "m" has a sound translation of $/ \mathrm{m} /$. Mark demonstrates rapid word recognition of mom. Mark does not automatically decode the word, mom.

\section{2) Case Scenario}

Joan is six. She fluent reads a passage from a Dr. Seuss book, "I do not like green eggs and ham. I do not like them Sam I Am." The teacher points to the word green and asks,

"How do you know this word?"

Joan points to the word green and replies, "I know this is green because green is the longest word, and see the beginning...," Joan points to the " $g$ ", "It [the $g$ ]hangs down like a hook." Joan goes on to explain her rapid word recognition strategies pointing to the word eggs, "I know this is eggs, see? The two hooks (points to the ggletters) are at the end."

The assumption that rapid word recognition is the same mental process as automatic word decoding is incorrect. Children can rapidly recognize words using many types of strategies. Rapid word recognition often has nothing to do with the ability to decode words or decode spelling patterns (Juel \& Roper/Schneider, 1985; Wolf, 2016). Some reading materials offered to beginning readers facilitate, not decoding, but rapid word recognition strategies.

\section{3) Case Scenario}

Diane is six, in first grade. She uses a beginning reading book that encourages her to look at pictures to recognize words. Diane fluently reads, "The tree is green. The ball is red."

The teacher explains, "These are sentence-pattern books. The children name an object then name the color of the object. The children tend to pay more attention to the pictures than the print" (A. Zaichenko, personal communication, 
October 11, 2018).

\section{4) Case Scenario}

This case details the differences between rapid word recognition and automatic word decoding. Tom is in first grade. Tom is falling behind in his reading development. The reading teacher checks to see if Tom can, not name lower case letter forms, but instead, if Tom can respond with the basic sound-translation or "read" the 26 letters. Tom can "read" each letter.

Next, the reading teacher checks to see if Tom can read the basic consonant-vowel-consonant (CVC) spelling pattern of /a/ words, such as, ran, tan, van, map, cat, gas, pal, ham-60 words. Tom does quite well. The teacher helps Tom with some words, modeling the blending of sounds into words. Tom's reading is not fluent. During this initial visit, the reading teacher has Tom read /o/ words, such as mom, $\log$, Tom... The /o/CVC words seem harder for Tom, in fact he is unable to decode his own name, Tom. Tom, asks for help. The reading teacher says, "I am not going to help you read this word." "Take the /o/ book home Tom," the teacher says, "Call me up when you read the word." About 30 minutes later the teacher's phone rings. It is Tom.

"It's my name, Tom, I read my name!" Tom is excited. Tom's mother gets on the phone and says, "Tom has been recognizing his name for years, on birthday cards, Christmas presents-this is the first time he has ever read his name."

These case scenarios demonstrate the different strategies children use to read. Beginning reading teachers must concern themselves with the types of strategies children are encouraged to use when first learning to read. When learning to read, children will utilize the reading strategies they are exposed to first (Castles \& Nation, 2008; Juel \& Roper/Schneider, 1985; Veenendaal et al., 2015). Unless taught to decode words from the beginning of instruction, children will use other strategies to recognize words (Juel \& Roper/Schneider, 1985). A first grade teacher describes a chilling reality:

"Children can learn to read many words by sight. But if somewhere along the way they do not learn to decode, they will not learn to read. It's these kids who get held back, and these same kids who drop out of school. You get so you can predict which ones it's going to be." (Wolf, 1998: p. 17, M. Nicholson, personal communication, March 20, 1998).

Years of known data confirms this teacher's observations. To prevent later reading difficulties, early reading instruction should focus on children practicing decoding (Mc Candliss et al., 2003). Children who exhibit poor foundational decoding skills are often the children who: a) develop poor reading comprehension (Kuhn et al., 2010), b) drop out of school (Denton \& Otaiba, 2011), and c) have lasting, poor literacy, thus academic struggles (Adams, 1990; Denton \& Otaiba, 2011; Juel, 1988).

\section{Why Text Matters: Improving Repeat Reading Teaching Strategies}

It is important for children to apply letter sound and spelling pattern knowledge 
as a primary reading strategy (Beck, 1998; Chard \& Osborn, 1999; Castles \& Nation, 2008; Mc Candliss et al., 2003). Further, the type of text children try to read shapes the reading strategies children use (Castles \& Nation, 2008; Juel \& Roper/Schneider, 1985; Veenendaal et al., 2015). Accordingly, the type of text beginning readers are asked to repeat read will determine the type of reading strategies children practice and develop. The following case scenarios demonstrate how beginning reading materials will foster different reading strategies.

\section{1) Case Scenario}

Hannah's first reading lessons involve reading pattern sentences, I like to Hannah fills in the blank and is able to fluently read, "I like to eat ice cream! I like to go swimming!"Hannah is reading many different spelling patterns. Text memorization, and sight word recognition are the initial reading strategies Hannah learns. When the teacher shows Hannah the word "to" out of the sentence pattern, Hannah is unable to read the word.

\section{2) Case Scenario}

Sometimes children learning to read will revert to looking at a picture and thus guess what a word "says". Luis is four. He reads "Dan ran to the... ice cream truck?" Luis is looking at the picture of an ice cream truck on the page. Luis looks up questioningly at the teacher. The teacher silently prompts with a finger-tap on the last word. Luis self-corrects, "van". Luis repeat reads, "Dan ran to the van!" This time when re-reading Luis's gaze remains on the text and there is an excited confidence in his voice. Luis reads by a) decoding CVC words, b) looking at a picture, c) guessing, and finally d) self-correcting re-using decoding skills. Luis wants to continue reading, and when given a choice, Luis chooses the decodable book to take home and read to his parents. "I can read this book!" Luis tells his parents. Luis seems motivated to read the decodable book because, a) reading is not viewed as an endless memorization, or guessing process, b) Luis is using his letter-sound knowledge to decode words, and c) Luis is proud that he is independently reading, and comprehending print, with little help from the teacher. Luis's reading is slow, and not fluent. Luis is having to attend to every letter in every word. Luis is slowly building decoding skills, not by repeat reading the same text, but by reading slightly different, and simple, decodable text.

\section{Developing Automaticity and Reading Fluency: A Theoretical Model}

There are two pathways to fluent reading 1) rapid word recognition, and 2) automatic word decoding. During beginning reading instruction, teaching strategies and text(s) should aim to develop automatic word decoding skills. Children will apply decoding skills if beginning reading text offers simple, decodable spelling patterns (Morris, 2015). The below model illustrates the two pathways beginning readers can take to develop fluent reading (Figure 1).

Rapid word recognition, sometimes called sight word recognition (Adams, 1990; Walton \& Walton, 2002) is initially a quick path to reading fluency. Repeat reading the exact same text develops rapid word recognition through the 


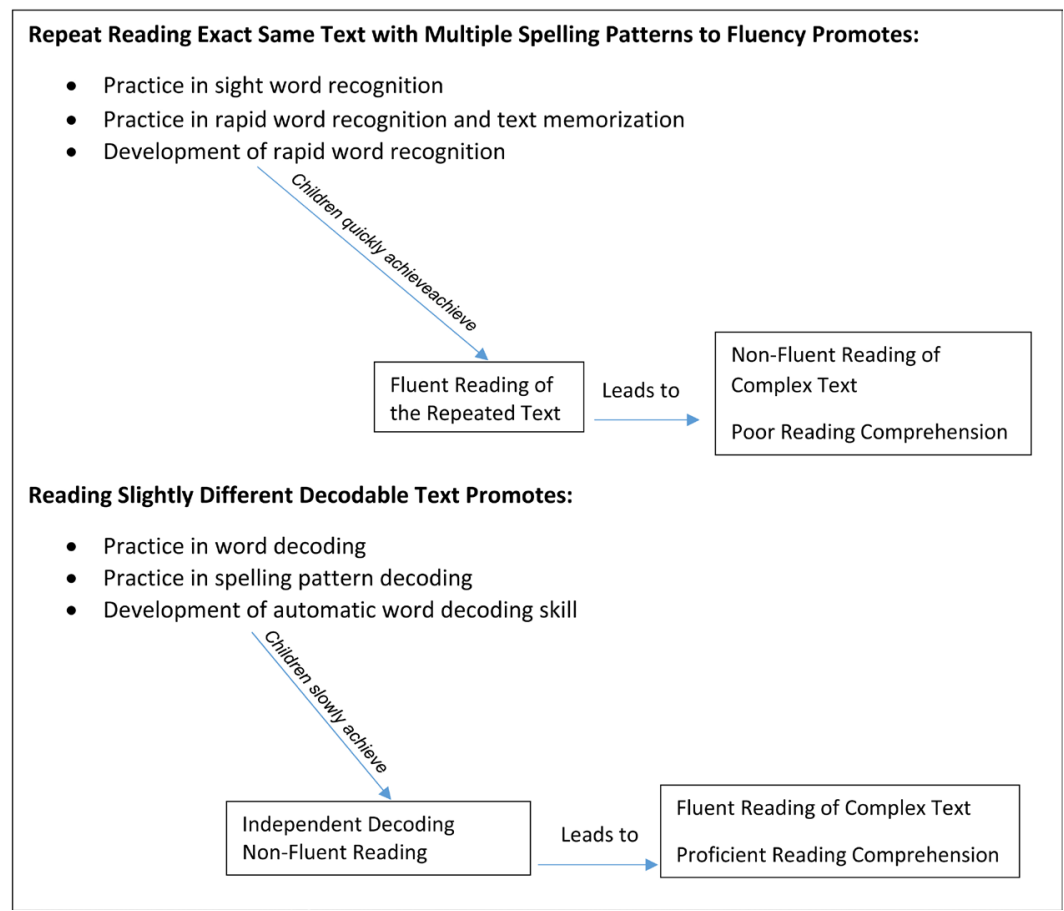

Figure 1. A theoretical model: beginning readers have two pathways to fluent reading.

pathway of text memorization. An example of text children repeat read is: There is no school today. Mother Cat has many little helpers. What a busy house! What a noisy house! (Scarry, 1986: p. 1).

In contrast, when reading slightly different, decodable text children must practice word decoding. An example of slightly different decodable text is: Nan ran. Nan ran to the van. Nan ran to the tan van. (Rasmussen \& Goldberg, 1985: p. 8). When children practice decoding, children take longer to reach effortless, automatic decoding, and reading fluency (Veenendaal et al., 2015). In the long run, fluency that arises from the roots of automatic decoding is what beginning readers must develop.

Adams' review of research confirms how proficient readers process "virtually" every individual letter of every word they read (Adams, 1990: p. 410). Beginning reading materials should help young readers practice the same actions of the skillful reader (Wolf, 2016). Teachers should not offer children text that is easily memorized. Teachers should offer young children slightly different, decodable text that ensures children's very first reading attempts develop the skill of processing every letter of every word.

\section{Use of Decodable Text: Research and Teaching Implications}

Currently the national Common Core standards recommend beginning reading materials be drawn from acclaimed children's literature in areas of adventure stories, folktales, legends, fables, fantasy, realistic fiction, and myth (Common Core State Standards, 2015). The titles of recommended beginning reading ma- 
terials offer a preview of the spelling patterns and text children are asked to decode: Over in the Meadow by John Langstaff, or Pancakes for Breakfast by Tomie De Paola (Common Core State Standards, 2015). Beautiful literature: not easy text for a beginning reader to apply decoding skills.

In contrast, decodable text for beginning readers may have drawbacks. The initial stories may bore children. One school of thought is decodable text, sentences like: Dan ran. The man ran would stifle children's motivation to read, or mix children up with such similar spellings (Adams, 1990). There is no found research to support these claims (Wolf, 1998; 2014).

There is convincing data that simple, decodable text is ideal for the beginning reader because a) during children's very first reading attempts, decodable text promotes the use of letter sound knowledge and spelling pattern knowledge as the primary reading strategy, and b) children are usually successful in applying their letter sound knowledge to decode words (Juel \& Roper/Schneider, 1985). In addition, it is readers who learn to respond to letter or spelling patterns, often called orthographic reading, who become the best readers in terms of decoding and reading comprehension (Castles \& Nation, 2008; Veenendaal et al., 2015). Verhoeven and Leeuwe's (2009) seminal 6-year study, with close to 3000 participants, confirmed it was the 5-year-old children who could read the basic CVC spelling pattern who were still the best readers in sixth grade.

Decodable text has the following benefits for children learning to read:

1) From the very first day, the reading lessons are kept as simple and easy as possible ensuring independent reading success in decoding and comprehension;

2) Words belong to the oral language of children so the children will derive meaning as words and sentences are successfully decoded;

3) The words in decodable texts belong to a consistent spelling pattern so the beginning reader has the advantage of learning by spelling pattern instead of by an accumulation of individual words with different spelling patterns;

4) The spelling patterns presented are stepping stones, upon which decoding of succeeding words may be based (top, stop, stops...)

5) Children are using, not rote memory, but their minds to read which sparks a desire to want to read more. That is, learning to read is motivating (Wolf, 1998; 2014).

Research supports the aforementioned points, a) highlighting spelling-to-sound regularities helps to develop children's automatic decoding skills (Greaney \& Arrow, 2012; Verhoeven \& Leeuwe, 2009), and, b) the activity of learning to read creates motivation to read (Paris \& Carpenter, 2004). Further, the theoretical model of the pathway to automaticity and fluent reading is supported by childhood teaching and learning theories.

\section{Reading Teacher Education: Bridging Theory to Classroom Practice}

The education of reading teachers should help teachers bridge childhood learn- 
ing theories into classroom practice (Agbenyega, 2009; National Institute for Literacy, NIFL, 2008; Wolf, 1998). Derived from Jean Piaget, Lev Vygotsky, and Maria Montessori's seminal work, there are three childhood learning principles which align with beginning reading instruction (Agbenyega, 2009; Cossentino, 2006; Tzuo, 2007). These three main principles also align with the theoretical model of the pathway to developing automaticity and fluent reading.

\section{1) Principle One: Provide the Necessary Materials for Learning}

The primary role of the teacher is to provide children with the necessary materials so children can easily learn (Montessori, trans. 1965, 1966; Piaget, trans. 1952). Montessori, and Piaget wrote how true learning and deep understanding are not efforts of memory (Montessori, trans., 1965, 1966; Piaget, trans., 1952). Instead of using rote-memorization, children must have the necessary materials to be able to use internal mental processing to construct knowledge (Gredler, 2009; Inhelder \& Piaget, trans. 1958; Piaget, trans. 1952). When children are learning to read, the teacher must give children the necessary materials so children can use the mental process of decoding to construct words (Bracken \& Crawford, 2010; Montessori, 1965, 1965). In the case of beginning reading instruction, the necessary materials are decodable text (Greaney \& Arrow, 2012; Wolf, 1998, 2016).

\section{2) Principle Two: Scaffolding Teaching Materials Facilitates Learning}

Piaget, Vygotsky, and Montessori all affirmed it is specifically organized, or scaffolded teaching materials which fosters learning in children (Inhelder \& Piaget, trans. 1958; Montessori, trans. 1965; trans. 1966; Piaget, trans. 1952; Vygotsky, trans. 1978). Montessori and Vygotsky claimed when teachers purposely scaffold educational materials, these materials enhance independent learning (Montessori, trans. 1965; trans. 1966; Vygotsky, trans. 1978). Scaffolding is a process of building learning curriculum, activities, and materials in a systematic order in which mastering each skill, leads to the ability to transfer the knowledge to master a higher order skill (Hmelo-Silver, Duncan, \& Chinn, 2007; Montessori, trans. 1965; trans. 1966; Piaget, trans. 1952; Vygotsky, trans. 1978).

To facilitate learning to read, teachers should learn how to scaffold reading materials (Cohen, \& Brady, 2011; Wolf, 1998, 2016). In the case of beginning reading instruction, the scaffolded materials are slightly different, decodable text. Scaffolding text helps children apply the prior constructed knowledge to construct new patterns of knowledge. The new patterns of knowledge children construct are new spelling patterns.

A valuable educational preparation for beginning reading teachers is to explore scaffolding of a) CVC words (Appendix), b) CVC sentence length, and c) decodable spelling patterns. Reading teachers should be taught how to scaffold simple spelling patterns, to more complex patterns for children to read: CVC pattern: bat, cat, fat... CVCC pattern: pass, doll, puff... CCVC pattern: skin, skip, stop, step, snip, spin, swim... CCVCC pattern: black, crack, brick, click, stick, trick, stuck, truck...A benefit of educating reading teachers on scaffolding 
spelling patterns, is reading teachers are then equipped to assess the quality of beginning reading programs and materials a school district might want to adopt.

\section{3) Principle Three: Authentic Practice}

Important to each childhood learning theorist, Piaget, Vygotsky, and Montessori was how authentic experience and repeated, authentic practice creates learning (Inhelder \& Piaget, trans. 1958; Montessori, trans. 1965; trans. 1966; Piaget, trans. 1952; Vygotsky, trans. 1978). In the process of learning to read, children must have authentic reading experience. Children must practice the print-to-sound decoding processing and comprehension of print. The theoretical model on pathways to reading fluency shows how it is the pathway of decoding simple spelling patterns that provides authentic, repeated practice of reading.

In summary, there are three guiding theories that facilitate children's learning to read a) provide necessary materials, b) scaffold the reading materials or text(s), and c) create opportunities for authentic reading practice. Teacher education can enable teachers to put these key principles into classroom practice. When put into action, the three childhood learning principles, and the theoretical model, combine to make a powerful beginning reading curriculum.

\section{Implications of the Theoretical Model for Future Research}

The theoretical model applies confirmed research evidence that beginning reading text should encourage children to pay attention to letter sound translations in order to practice decoding simple words. Further, when the text is slightly different, children must pay attention to every letter in every word, practicing the behaviors of proficient readers. More research is needed on beginning reading text, and scaffolding text. Research is needed on beginning reading teachers' abilities to assess and evaluate beginning reading text(s).

\section{Conclusion}

This article reviewed the relationship between the concepts of reading automaticity and reading fluency. Automatic decoding skills are needed for fluent reading, and in turn reading comprehension (Kuhn et al., 2010; Wolf, 2016). A theoretical model postulates that depending on the type of text, children are asked to read, children will either practice rapid word recognition strategies, or children will practice word decoding strategies. The latter, slower strategy of practicing word decoding with attention to letters and spelling patterns helps children develop decoding automaticity, and thus fluency arising from the roots of automaticity.

The simple, theoretical model is backed by research and childhood learning theories of Piaget, Vygotsky, and Montessori. Education of beginning reading teachers can help bridge these theories into classroom practice. When the beginning reader is not memorizing text and is instead reading by using the mental process of decoding, a spark ignites a desire; children want to read more, learn more. 


\section{References}

Adams, M. J. (1990). Beginning to Read: Thinking and Learning about Print. Cambridge, MA: MIT Press.

Agbenyega, J. (2009). The Australian Early Development Index, Who Does It Measure: Piaget or Vygotsky's Child? Australasian Journal of Early Childhood, 34, 31-37.

Beck, I. (1998). Understanding Beginning Reading: A Journey through Teaching and Research. In F. Lehr, \& J. Osborn (Eds.), Literacy for All: Issues in Teaching and Learning (pp. 11-31). New York: Guilford.

Bracken, B. A., \& Crawford, E. (2010). Basic Concepts in Early Childhood Educational Standards: A 50-State Review. Early Childhood Education Journal, 37, 421-430. https://doi.org/10.1007/s10643-009-0363-7

Castles, A., \& Nation, K. (2008). Learning to Be a Good Orthographic Reader. Journal of Research in Reading, 31, 1-7. https://doi.org/10.1111/j.1467-9817.2007.00367.x

Chard, D. J., \& Osborn, J. (1999). Phonics and Word Recognition Instruction in Early Reading Programs: Guidelines for Accessibility. Learning Disabilities Research \& Practice, 14, 107-117. https://doi.org/10.1207/sldrp1402_4

Chomsky, C. (1976). “After Decoding: What?” Language Arts, 3, 288-296.

Cohen, E. J., \& Brady, M. P. (2011). Acquisition and Generalization of Word Decoding in Students with Reading Disabilities by Integrating Vowel Pattern Analysis and Children's Literature. Education and Treatment of Children, 34, 81-113. https://doi.org/10.1353/etc.2011.0006

Common Core State Standards. (2015). Oregon Common Core State Standards for English Language Arts \& Literacy in History/Social Studies, Science, and Technical Subjects: Appendix B: Text Exemplars (14-39 for Kindergarten and First Grade). http://www.ode.state.or.us/wma/teachlearn/commoncore/ela-appendix-b.pdf

Common Core State Standards Initiative. (2015). Preparing America's Students for College \& Career. http://www.corestandards.org/about-the-standards/

Cossentino, J. M. (2006). Big Work: Goodness, Vocation, and Engagement in the Montessori Method. Curriculum Inquiry, 36, 63-92. https://doi.org/10.1111/j.1467-873X.2006.00346.x

Deeney, T. A. (2010). One-Minute Fluency Measures: Mixed Messages in Assessment and Instruction. The Reading Teacher, 63, 440-450. https://doi.org/10.1598/RT.63.6.1

De Graaff, S., Bosman, A. M. T., Hasselman, F., \& Verhoeven, L. (2009). Benefits of Systematic Phonics Instruction. Scientific Studies of Reading, 13, 318-333. https://doi.org/10.1080/10888430903001308

Denton, C., \& Otaiba, S. (2011). Teaching Word Identification to Students with Reading Difficulties and Disabilities. Focus on Exceptional Children, 43, 1-16.

Ehri, L. C. (2005). Learning to Read Words: Theory, Findings, and Issues. Scientific Studies of Reading, 10, 277-299. https://doi.org/10.1207/s1532799xssr0902_4

Faulkner, H. J., \& Levy, B. A. (1999). Fluent and Nonfluent Forms of Transfer in Reading: Words and Their Message. Psychonomic Bulletin \& Review, 6, 111-116. https://doi.org/10.3758/BF03210817

Fleisher, L. S., Jenkins, J. R., \& Pany, D. (1979). Effects on Poor Readers' Comprehension of Training in Rapid Decoding. Reading Research Quarterly, 1, 30-48. https://doi.org/10.2307/747430

Greaney, K., \& Arrow, A. (2012). Phonological-Based Assessment and Teaching within a 
First Year Reading Program in New Zealand. Australian Journal of Language and Literacy, 35, 9-32.

Gredler, M. E. (2009). Hiding in Plain Sight: The Stages of Mastery/Self-Regulation in Vygotsky's Cultural-Historical Theory. Educational Psychologist, 44, 1-19. https://doi.org/10.1080/00461520802616259

Guerin, A., \& Murphy, B. (2015). Repeat Reading as a Method to Improve Reading Fluency for Struggling Adolescent \& Adult Literacy. Journal of Adolescent \& Adult Literacy, 58, 551-560. https://doi.org/10.1002/jaal.395

Hicks, C. P. (2009). A Lesson on Reading Fluency Learned from the Tortoise and the Hare. The Reading Teacher, 63, 319-323. https://doi.org/10.1598/RT.63.4.7

Hmelo-Silver, C. E., Duncan, R. G., \& Chinn, C. A. (2007). Scaffolding and Achievement in Problem-Based and Inquiry Learning: A Response to Kirschner, Sweller, and Clark. Educational Psychologist, 42, 99-107. https://doi.org/10.1080/00461520701263368

Hoien-Tengesdal, I., \& Tonnessen, F. (2011). Health and Disability: The Relationship between Phonological Skills and Word Decoding. Scandinavian Journal of Psychology, 52, 93-103. https://doi.org/10.1111/j.1467-9450.2010.00856.x

Homan, S. P., Klesius, J. P., \& Hite, C. (1993). Effects of Repeated Readings and Nonrepetitive Strategies on Students' Fluency and Comprehension. Journal of Educational Research, 87, 94-99. https://doi.org/10.1080/00220671.1993.9941172

Inhelder, B., \& Piaget, J. (1958). The Growth of Logical Thinking from Childhood to Adolescence (A. Parsons, \& S. Milgram, Trans.). Basic Books, Inc.

https://doi.org/10.1037/10034-000

Juel, C. (1988). Learning to Read and Write: A Longitudinal Study of 54 Children from First through Fourth Grades. Journal of Educational Psychology, 80, 437-447. https://doi.org/10.1037/0022-0663.80.4.437

Juel, C., \& Roper/Schneider, D. (1985). The Influence of Basal Readers on First Grade Reading. Reading Research Quarterly, 20, 134-152. https://doi.org/10.2307/747751

Keyes, S. E., Cartledge, G., Gibson, Jr. L., \& Robinson-Ervin, P. (2016). Programming for Generalization of Oral Reading Fluency using Computer-Assisted Instruction and Changing Fluency Criteria. Education and Treatment of Children, 39, 141-172. https://doi.org/10.1353/etc.2016.0011

Kostewicz, D., \& Kubina, R. (2010). Comparison of Two Reading Fluency Methods: Repeated Readings to a Fluency Criterion and Interval Sprinting. Reading Improvement, 47, 43-63.

Kuhn, M. R. (2005). A Comparative Study of Small Group Fluency Instruction. Reading Psychology, 26, 127-146. https://doi.org/10.1080/02702710590930492

Kuhn, R. M., Schwanenflugel, P. J., \& Meisinger, E. B. (2010). Aligning Theory and Assessment Fluency: Automaticity, Prosody and Definitions of Fluency. Reading Research Quarterly, 45, 230-251. https://doi.org/10.1598/RRQ.45.2.4

Labbo, L. D., \& Teale, W. H. (1990). Cross-Age Reading: A Strategy for Helping Poor Readers. The Reading Teacher, 43, 362-369.

La Berge, D., \& Samuels, S. J. (1974). Toward a Theory of Automatic Information Processing in Reading. Cognitive Psychology, 6, 293-323. https://doi.org/10.1016/0010-0285(74)90015-2

Logan, G. D. (1997). Automaticity and Reading: Perspectives from the Instance Theory of Automatization. Reading \& Writing Quarterly, 13, 123-147. https://doi.org/10.1080/1057356970130203

Mc Candliss, B., Beck, I. L., Sandak, R., \& Perfetti, C. (2003). Focusing Attention on De- 
coding for Children with Poor Reading Skills: Design and Preliminary Tests of the Word Building Intervention. Scientific Studies of Reading, 7, 75-104. https://doi.org/10.1207/S1532799XSSR0701_05

Montessori, M. (1965). The Advanced Montessori Method (Vol. 1, F. Simmonds, Trans.). New York, NY: Schocken Books.

Montessori, M. (1966). The Discovery of the Child (M. A. Johnstone, Trans.). Thiruvanmiyur, Madras: Kalakshetra Publications.

Morris, D. (2015). Preventing Early Reading Failure. The Reading Teacher, 68, 502-509. https://doi.org/10.1002/trtr.1346

National Institute for Literacy (2008). Developing Early Literacy: Report of the National Early Literacy Panel. Jessup, MD: National Center for Family Literacy.

National Institute of Child Health and Human Development (2000). Report of the National Reading Panel: Teaching Children to Read; An Evidence-Based Assessment of the Scientific Research Literature on Reading and Its Implications for Reading Instruction. Washington DC: U.S. Government Printing Office of Health Publish No. 00-4754.

O’Shea, L. J., Sindelar, P. T., \& O’Shea, D. J. (1985). The Effects of Repeated Readings and Attentional Cues on Reading Fluency and Comprehension. Journal of Reading Behavior, 17, 129-142. https://doi.org/10.1080/10862968509547535

Paige, D. D., Rasinski, T. V., \& Magpuri-Lavell, T. (2012). Is Fluent, Expressive Reading Important for High School Readers? Journal of Adolescent \& Adult Literacy, 56, 67-76. https://doi.org/10.1002/JAAL.00103

Paris, S., \& Carpenter, R. (2004). Children's Motivation to Read. In J. Hoffman, \& D. Schallert (Eds.), The Texts in Elementary Class-Rooms (pp. 61-82). Mahwah, NJ: Eflbaum.

Piaget, J. (1952). The Origins of Intelligence in Children (M. Piercy, \& D. E. Berlyne, Trans.). New York, NY: International Universities Press, Inc. https://doi.org/10.1037/11494-000

Rasinski, T. V. (2012). Why Reading Fluency Should Be Hot! The Reading Teacher, 65, 516-522. https://doi.org/10.1002/TRTR.01077

Rasmussen, D., \& Goldberg, L. (1985). A Pig Can Jig Part I. Basic Reading Series, E, Chicago, IL: Science Research Associates, McGraw-Hill.

Samuels, S. J. (1979). The Method of Repeated Readings. The Reading Teacher, 32, 403-408.

Samuels, S. J. (1985). Automaticity and Repeated Reading. In J. Osborn, P. T. Wilson, \& R. C. Anderson (Eds.), Reading Education: Foundations for a Literate America (pp. 215-230). Lexington, MA: Lexington Books.

Samuels, S. J., \& Flor, R. F. (1997). The Importance of Automaticity for Developing Expertise in Reading. The Reading \& Writing Quarterly, 13, 107-118. https://doi.org/10.1080/1057356970130202

Samuels, S. J., Schermer, N., \& Reinking, D. (1992). Reading Fluency: Techniques for Making Decoding Automatic. In S. J. Samuels, \& A. E. Farstrup (Eds.), What Research Says about Reading Instruction (2nd ed., pp. 124-144). Newark, DE: International Reading Association.

Scarry, R. (1986). Richard Scarry's Splish-Splash Sounds. Racine, WI: Western Publishing Company, Inc.

Schwanenflugel, P. J., Meisinger, E. B., Wisenbaker, J. M., Kuhn, M. R., Strauss, G. P, \& Morris, R. D. (2006). Becoming a Fluent and Automatic Reader in the Early Elementary School Years. Reading Research Quarterly, 41, 496-522.

https://doi.org/10.1598/RRQ.41.4.4 
Sindelar, P. T., Monda, L. S., \& O’Shea, L. J. (1990). Effects of Repeated Readings on Instructional and Mastery-Level Readers. Journal of Educational Research, 83, 220-226. https://doi.org/10.1080/00220671.1990.10885959

Therrien, W. J., \& Hughes, C. (2008). Comparison of Repeated Reading and Question Generation on Student's Reading Fluency and Comprehension. Learning Disabilities: A Contemporary Journal, 6, 1-16.

Tzuo, P. W. (2007). The Tension between Teacher Control and Children's Freedom in a Child-Centered Classroom: Resolving the Practical Dilemma through a Closer Look at the Related Theories. Early Childhood Education Journal, 35, 33-39. https://doi.org/10.1007/s10643-007-0166-7

Valencia, S. W., Smith, T. A., Reece, A. M., Li, M., Wixson, K. K., \& Newman, H. (2010). Oral Reading Fluency Assessment: Issues of Construct, Criterion, and Consequential Validity. Reading Research Quarterly, 45, 270-291. https://doi.org/10.1598/RRQ.45.3.1

Veenendaal, N. J., Groen, M. A., \& Verhoeven, L. (2015). What Oral Text Reading Fluency Can Reveal about Reading Comprehension. Journal of Research in Reading, 38, 213-225. https://doi.org/10.1111/1467-9817.12024

Verhoeven, L., \& Leeuwe, J. V. (2009). Modeling the Growth of Word-Decoding Skills: Evidence from Dutch. Scientific Studies of Reading, 13, 205-223. https://doi.org/10.1080/10888430902851356

Vygotsky, L. S. (1978). Mind in Society: The Development of Higher Psychological Processes (A. R. Luria, Trans.). Cambridge, MA: Harvard University Press.

Walton, P., \& Walton, L. (2002). Beginning Reading by Teaching Rime Analogy: Effects on Phonological Skills, Letter-Sound Knowledge, Working Memory, and Word-Reading Strategies. Scientific Studies of Reading, 6, 79-115. https://doi.org/10.1207/S1532799XSSR0601_04

Wolf, G. M. (1998). The Three Ingredient Reading Program: You Can Teach Your Child to Read. Mesa, AZ: Blue Bird Publishing.

Wolf, G. M. (2014). Differences in Mean Number of Consonant-Vowel-Consonant Words Decoded between Letter-Sound Readers and Non Letter-Sound Readers. Open Journal of Nursing, 4, 409-450. https://doi.org/10.4236/ojn.2014.46047

Wolf, G. M. (2016). Letter-Sound Reading: Teaching Preschool Children Print-to-Sound Processing. Early Childhood Education Journal, 44, 11-19. https://doi.org/10.1007/s10643-014-0685-y 


\section{Appendix}

Consonant-Vowel-Consonant (CVC) Basic Spelling Pattern: Scaffolded for Reading Ease.

\section{/a/ book}

$\begin{array}{llll}\text { can } & \text { bat } & \text { ham } & \text { cab bag bad cap gal gas } \\ \text { Dan } & \text { cat } & \text { Pam } & \text { dab gag dad gap Hal } \\ \text { fan } & \text { fat } & \text { ram } & \text { gab hag Dad lap pal } \\ \text { man } & \text { hat } & \text { Sam } & \text { jab lag had map Al } \\ \text { Nan } & \text { mat yam } & \text { lab nag lad tap } \\ \text { pan } & \text { pat am } & \text { tab rag mad zap } \\ \text { ran } & \text { rat } & \text { sag pad } \\ \text { tan } & \text { sat } & \text { tag sad } \\ \text { van } & \text { at } & \text { wag add } \\ \text { an } & & \end{array}$

/o/ book

$\begin{array}{ll}\text { mom } & \text { con cot bob cog cod bop off } \\ \text { Mom } & \text { Don dot Bob dog god cop } \\ \text { Tom } & \text { Ron got cob fog God hop } \\ & \text { on hot job hog nod mop } \\ \text { jot lob jog pod pop } \\ \text { lot mob log rod sop } \\ \text { not rob } \\ \text { pot Rob } \\ \text { rot sob }\end{array}$

$/ \mathrm{u} /$ book

\begin{tabular}{llllll} 
bun & but & bum & \multicolumn{2}{l}{ cub bug bud cup bus } \\
fun & cut & gum & hub dug cud pup Gus \\
gun & gut & hum & nub hug dud & pus \\
pun & hut & rum & pub jug mud & us \\
run & jut & sum & rub lug & \\
sun & nut & yum & sub mug & \\
nun & ut & & tub rug & \\
/i/ book & & & & \\
fin bit & dim bib & big & bid & dip & \\
kin fit & him fib & dig & did hip & \\
pin hit & Jim rib & fig & hid lip \\
sin kit & Kim & jig & lid & nip \\
tin lit & rim & pig & lid & rip \\
win nit & Tim & rig & Sid & sip \\
in pit & & wig & tip & \\
quit & & & zip & \\
sit & & &
\end{tabular}


it

ill

sis

quiz

\begin{tabular}{lllll}
\multicolumn{3}{l}{ /e/ book } & & \\
Ben & bet & beg & bed & Mel \\
den & get & keg & fed & Nel \\
hen & jet & leg & Jed & elf \\
Ken & let & Meg led & elk \\
pen & net & Peg & red hem \\
ten & pet & & Ted pep \\
& set & & wed web \\
& vet & & Ed ebb \\
& wet & & Wes \\
& yet & & yes
\end{tabular}

